\title{
A COMPARATIVE STUDY OF IN-VITRO NITRIC OXIDE SCAVENGING ACTIVITY OF BALOFLOXACINVS PRULIFLOXACIN
}

\author{
PUJA RANKA ${ }^{1 *}$, KARTHIK VP \\ ${ }^{1}$ Sri Ramachandra Dental College, Chennai, Tamil Nadu, India. ${ }^{2}$ Department of Pharmacology, Sri Ramachandra Medical College \& \\ Research Institute, Chennai, Tamil Nadu, India. Email: apujaranka@gmail.com
}

Received: 14 November 2016, Revised and Accepted: 28 November 2016

\section{ABSTRACT}

Objectives: To compare the free radical scavenging activity and antioxidant potentials of balofloxacin versus prulifloxacin.

Methods: Nitric oxide (NO) radical scavenging activity was determined using the method of Garret (1964). Sodium nitroprusside in aqueous solution at physiological pH spontaneously generates NO, which interacts with oxygen to produce nitrite ions which can be determined by the use of Griess ilosvay reaction. $2 \mathrm{~mm}$ of $10 \mathrm{~mm}$ sodium nitroprusside in $0.5 \mathrm{ml}$ phosphate buffer saline (pH 7.4) was mixed with $0.5 \mathrm{ml}$ prulifloxacin and balofloxacin at various concentrations and the mixture incubated at $25^{\circ} \mathrm{C}$ for 150 minutes. From the incubated mixture $0.5 \mathrm{ml}$ was taken out and added into $1.0 \mathrm{ml}$ sulfanilic acid reagent (30 in 20\% glacial acetic acid) and incubated at room temperature for 5 minutes. Finally, 1.0 ml naphthylethylenediamine dihydrochloride $(0.1 \% \mathrm{w} / \mathrm{v})$ was mixed and incubated at room temperature for 30 minutes. The resultant absorbance was recorded at 540 nm using a spectrometer. The percentage inhibition was calculated using the formula: Percentage inhibition $=\frac{\mathrm{Abs}_{\text {control }}-\mathrm{Abs}_{\text {sample }}}{\mathrm{Abs}_{\text {control }}} \times 100$

Results: At concentration of $10,20,30$, and $40 \mu \mathrm{g} / \mathrm{ml}$ percentage inhibition observed with prulifloxacin and balofloxacin was $40.94,53.09$, 66.25 , 88.06 and $34.49,49.09,60.42$, and 73.14 , respectively.

Conclusion: Thus, this in vitro study suggests that both prulifloxacin and balofloxacin possess antioxidant properties. At the lower doses both the drugs show similar antioxidant profile, while at the higher doses the antioxidant potential of prulifloxacin is significantly high than balofloxacin. However, the preference of selecting one over the other depends on the indication as well as the risk-benefit ratio.

Keywords: In vitro, Nitric oxide, Prulifloxacin, Balofloxacin.

(C) 2017 The Authors. Published by Innovare Academic Sciences Pvt Ltd. This is an open access article under the CC BY license (http://creativecommons. org/licenses/by/4. 0/) DOI: http://dx.doi.org/10.22159/ajpcr.2017.v10i1.16178

\section{INTRODUCTION}

Oxidative stress is suspected to be an important etiological factor in the pathogenesis of various diseases such as Parkinson's disease, Alzheimer's disease, Huntington's disease, depression, and multiple sclerosis. Oxidative stress is also linked to certain cardiovascular disease since oxidation of the low-density lipoprotein in the vascular endothelium is a precursor to plaque formation. Oxidative stress is likely to be involved in age-related development of cancer. The reactive species produced in oxidative stress can cause direct damage to the DNA and are therefore mutagenic, and it may also suppress apoptosis and promote proliferation, invasiveness, and metastasis.

Although, reactive oxygen species (ROS) and reactive nitrogen species play an important roles in many biological processes and are involved in host defense, overproduction of these species such as hydroxyl radical $(. \mathrm{OH})$, hydrogen peroxide $\left(\mathrm{H}_{2} \mathrm{O}_{2}\right)$, superoxide anions (O2.-), and nitric oxide (NO.), as well as peroxyl nitrite contributes to the immunopathology of a vast variety of conditions including inflammatory diseases, cancer, atherosclerosis, diabetes mellitus, hypertension, AIDS, and aging (Darley-Usmar et al., 1995; Lee et al., 2000) and also contribute to food deterioration [1].

An antioxidant is a molecule stable enough to donate an electron to a rampaging free radical and neutralize it, thus reducing its capacity to damage. These antioxidants delay or inhibit cellular damage mainly through their free radical scavenging property [2].

The fluoroquinolones can be classified into four generations based on antimicrobial activity. First-generation agents, which are used less often today, have moderate Gram-negative activity and minimal systemic distribution. The second-generation quinolones have expanded Gram-negative activity and atypical pathogen coverage, but limited Gram-positive activity [3]. These agents are most active against aerobic Gram-negative bacilli. Third-generation quinolones retain expanded Gram-negative and atypical intracellular activity but have improved Gram-positive coverage. Finally, fourth-generation agents improve Gram-positive coverage, maintain Gram-negative coverage, and gain anaerobic coverage [4].

Various fluoroquinolones are being used in medicine for treatment of number of conditions mainly based on its antimicrobial property. The data on the antioxidant property of fluroquinolones are scanty. Prulifloxacin and balofloxacin are two such fluroquinolones with additional antioxidant property along with their traditional antimicrobial effects. Prulifloxacin is a synthetic fluroquinolone prescribed to treat complicated and uncomplicated urinary tract infections, communityacquired respiratory tract infections; gastroenteritis including infectious diarrhea. Balofloxacin is recently approved quinolone antibiotic prescribed for infective ophthalmitis, sinusitis, chronic bronchitis, community acquired pneumonia, and skin infections $[5,6]$. No studies have been done so far comparing the antioxidant potentials of prulifloxacin and balofloxacin. Hence, in our study, we have attempted to compare the free radical scavenging activity of prulifloxacin and balofloxacin using in vitro NO radical. The preference of selecting one over the other depends on the indication and risk-benefit ratio.

\section{METHODS}

Samples preparation

About $10 \mathrm{mg} / \mathrm{ml}$ stock solutions of prulifloxacin and balofloxacin were prepared with ethanol $(60 \mu \mathrm{M})$ 
Principle

NO assay was based on the principle that sodium nitroprusside in aqueous solution at physiological $\mathrm{pH}$ spontaneously produces NO which acts with oxygen to produce nitrite ions, which can be found by the use of griess ilosvay reaction (Fig. 1) [7].

\section{Drug source}

- Balofloxacin was procured from LUPIN Pharmaceuticals Inc.

- Prulifloxacin was procured from CIPLA Limited.

Reference antioxidant: Vitamin C.

\section{Procedure}

The drug was dissolved in distilled water for this quantification. Sodium nitroprusside $(5 \mathrm{~mm})$ in standard phosphate buffer saline $(0.025 \mathrm{M}$, and $\mathrm{pH} \mathrm{7.4)} \mathrm{was} \mathrm{incubated} \mathrm{with} 100 \mathrm{mg} / \mathrm{ml}$ of sample, and tubes were incubated at $29^{\circ} \mathrm{C}$ for $3 \mathrm{hrs}$. A control experiment without the test compounds but with an equivalent amount of buffer was conducted in an identical manner. After $3 \mathrm{hrs}$ incubated samples were diluted with $1 \mathrm{ml}$ of Griess reagent. The absorbance of the color developed during diazotization of nitrite with sulfanilamide and its subsequent coupling with naphthyl ethylenediamine hydrochloride was observed at 550 $\mathrm{nm}$ on spectrophotometer. The same procedure was conducted with ascorbic acid which was standard in comparison to sample [8].

\section{Calculation:}

Percentage inhibition $=\frac{\mathrm{Abs}_{\text {control }}-\mathrm{Abs}_{\text {sample }}}{\mathrm{Abs}_{\text {control }}} \times 100$

\section{RESULTS}

The percentage inhibition of NO noted with balofloxacin at 10,20,30, and $40 \mathrm{mg}$ are $34.49,49.09,60.42$, and 73.14 and percentage inhibition of NO noted with prulifloxacin at 10,20,30, and $40 \mathrm{mg}$ are 40.94, 53.09, 66.25 , and 88.06, respectively (Tables 1 and 2).

\section{DISCUSSION}

The free radical oxidative stress has been implicated in the pathology of a wide variety of clinical disorders. Numerous physiological and biochemical processesin the human body mayproduce oxygen-centered free radicals and other ROS as by-products. Overproduction of such free radicals can cause oxidative damage to biomolecules, eventually leading to many chronic diseases such as cancer, diabetes, and ageing. Antioxidants may offer resistance against the oxidative stress by scavenging free radicals, inhibiting lipid peroxidation and by many other mechanisms and thus prevent disease [9].

Fluroquinolones are large groups of antibiotics affecting inflammation, immunomodulation, cell proliferation, and angiogenesis. These

Table 1: \% Inhibition of NO by prulifloxacin

\begin{tabular}{lll}
\hline Dose (mg) & Vitamin C & Prulifloxacin \\
\hline 10 & 56.09 & 42.94 \\
20 & 67.96 & 56.09 \\
30 & 84.09 & 66.25 \\
40 & 98.50 & 88.06 \\
\hline
\end{tabular}

NO: Nitric oxide

Table 2: \% Inhibition of NO by balofloxacin

\begin{tabular}{lll}
\hline Dose (mg) & Vitamin C & Balofloxacin \\
\hline 10 & 56.09 & 34.49 \\
20 & 67.96 & 49.09 \\
30 & 84.09 & 60.42 \\
40 & 98.50 & 73.14 \\
\hline
\end{tabular}

antibiotics have been shown to exhibit antioxidant potential; however, the exact mechanisms of how the drugs work are unclear. It has been suggested that the antioxidant capacity of fluroquinolones is based on the inhibition of reactions leading to ROS production and/or on direct radical scavenging activity. We have undertaken systematic examinations of the reaction of FQs with ROS. Recently, we found that FQs are effective scavengers of NO [10].

NO is an important chemical mediator generated by endothelial cells, macrophages, neurons, and involved in the regulation of various physiological processes. Excess concentration of NO is implicated in the cytotoxic effects observed in various disorders such as AIDS, cancer, Alzheimer's, and arthritis. The oxygen reacts with the excess NO to generate nitrite and peroxynitrite anions, which act as free radicals. Baghiani et al. reported that the antioxidant effect of prulifloxacin was greater than any other fluroquinolones in an in vitro study. A recent in vitro study has reported that clinical concentrations of balofloxacin exert antioxidant properties [11]. Talla and Veerareddy have concluded that fluroquinolones induce more ROS and produce substantial depletion in both superoxide dismutase and glutathione levels particularly with ciprofloxacin that leads to cell damage, which is quite contrasting to our result [12].

Goswami et al. concluded that the presence of antioxidants rescues bacteria against the antibacterial action of fluoroquinolones. These observations are of significance, as fluoroquinolones are important antibiotics with immense therapeutic value, and further investigations surrounding the intake of antioxidants on the effects of fluoroquinolones for the treatment of infections [13].

The percentage inhibition of $\mathrm{NO}$ at the low dose $(10 \mathrm{mg})$ of balofloxacin and prulifloxacin appears to be almost similar from the Graphs 1 and 2. But at subsequent doses, the gap between balofloxacin and prulifloxacin widens up, which indicates a significant dose-dependent antioxidant potential of prulifloxacin over balofloxacin

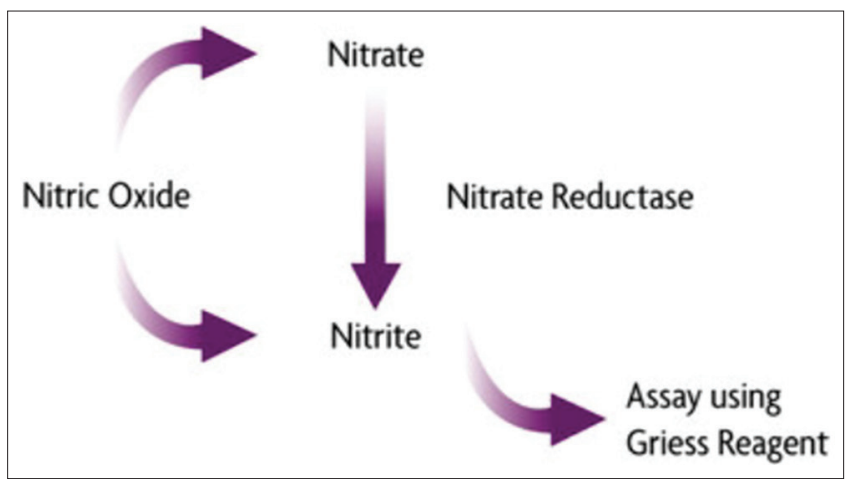

Fig. 1: Principle of nitric oxide assay

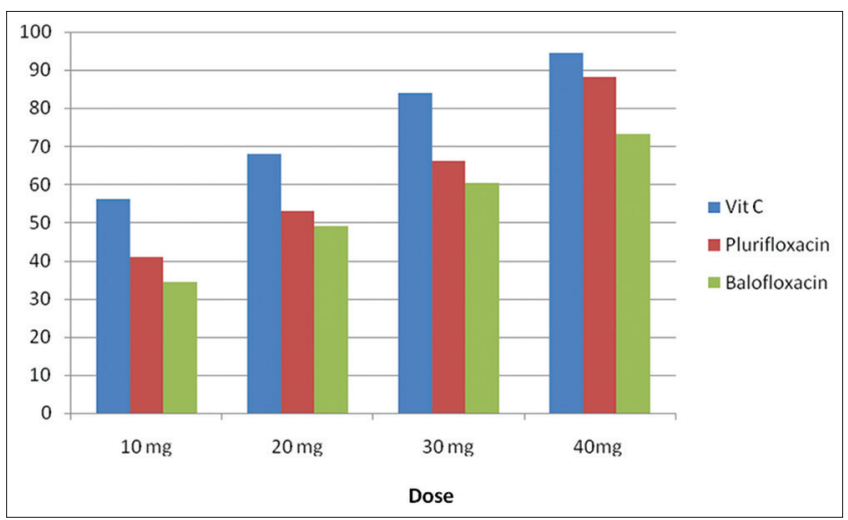

Graph 1: \% Inhibition of nitric oxide by prulifloxacin and balofloxacin 


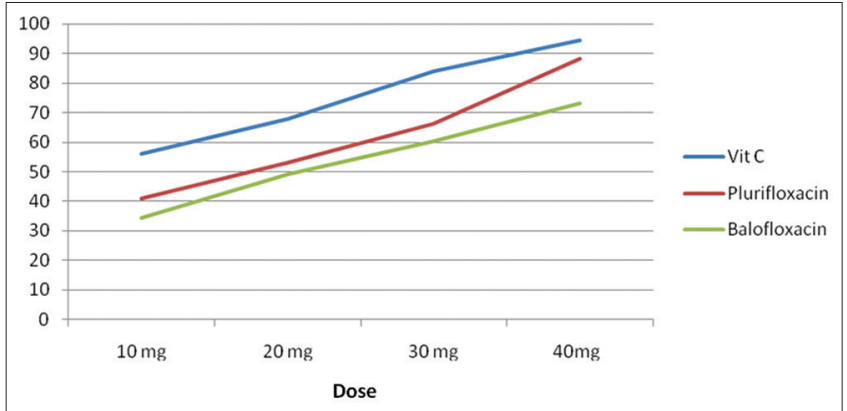

Graph 2: \% Inhibition of nitric oxide by prulifloxacin and balofloxacin Vs Vitamin C

\section{CONCLUSION}

In this study, prulifloxacin, a fluroquinolone showed significant and dosedependent free radical scavenging activity by NO radical scavenging assay. Free radical scavenging activity of balofloxacin was less significant than prulifloxacin but was consistent and non-concentration dependent.

Our in vitro study proves that prulifloxacin has better antioxidant activity than balofloxacin. Therefore, prulifloxacin which is an antimicrobial drug may be effective also as an antioxidant in a wide variety of disease conditions caused by oxidative stress.

\section{REFERENCES}

1. Awah FM, Verla AW. Antioxidant activity, nitric oxide scavenging activity and phenolic contents of Ocimum gratissimum leaf extract. J
Med Plants Res 2010;4(24):2479-87.

2. Kim GH, Kim JE, Rhie SJ, Yoon S. The role of oxidative stress in neurodegenerative diseases. Exp Neurobiol 2015;24(4):325-40.

3. Oliphant CM, Green GM. Quinolones: A comprehensive review. Am Fam Physician 2002;65(3):455-65.

4. Zahin M, Aqil F, Ahmad I. The in vitro antioxidant activity and total phenolic content of four Indian medicinal plants. Int J Pharm Pharm Sci 2009; 1 Suppl 1:88-95

5. Subhashini N, Nagarajan G, Kavimani S. In vitro antioxidant and anticholinesterase activities of Garcinia combogia. Int J Pharm Pharm Sci 2011;3:129-32.

6. Saux NL. The treatment of acute bacterial sinusitis: No change is good medicine. CMAJ 2008;178(7):865-6.

7. Karthik VP, David DC. In-vitro nitric oxide scavenging activity of ethanol extract of Canthium coramandelium. Int J Pharm Bio Sci 2015;6(4):695-700.

8. Thiruvengadam R, Sankar S. Comparison of in vitro antioxidant activity of olmesartan and amlodipine. Int J Pharmacol Clin Sci 2015;4(4):90-3.

9. Uttara B, Singh AV, Zamboni P, Mahajan RT. Oxidative stress and neurodegenerative diseases: A review of upstream and downstream antioxidant therapeutic options. Curr Neuropharmacol 2009;7(1):65-74.

10. Kładna A, Michalska T, Berczyński P, Kruk I, Aboul-Enein HY. Evaluation of the antioxidant activity of tetracycline antibiotics in vitro. Luminescence 2012;27(4):249-55.

11. Parul R, Kundu SK, Saha P. In vitro nitric oxide scavenging activity of methanol extracts of three Bangladeshi medicinal plants. Pharm Innov J 2013;1(12):83.

12. Talla V, Veerareddy PR. Oxidative stress induced by fluoroquinolones on treatment for complicated urinary tract infections in Indian patients. J Young Pharm 2011;3(4):304-9.

13. Goswami M, Mangoli SH, Jawali N. Involvement of reactive oxygen species in the action of ciprofloxacin against Escherichia coli. Antimicrob Agents Chemother 2006;50(3):949-54. 